\title{
Szarvasmarhák legelőhasználata és legeléspreferenciája
}

\author{
Balogh Nóra ${ }^{1}$, Tóthmérész Béla ${ }^{1}$, Valkó Orsolya ${ }^{1}$, \\ Deák Balázs ${ }^{2}$,Miglécz Tamás ${ }^{1}$, Tóth Katalin², Molnár Zsolt ${ }^{3}$, \\ Vadász Csaba ${ }^{4}$,Tóth Edina ${ }^{5}$, Kiss Réka ${ }^{1}$, Sonkoly Judit ${ }^{5}$, Török \\ Péter $^{5}$, Antal Károly ${ }^{6}$, Tüdősné Budai Júlia ${ }^{6}$ és Kelemen András ${ }^{1,7^{*}}$ \\ ${ }^{1}$ Debreceni Egyetem TTK Ökológiai Tanszék 4032 Debrecen, Egyetem tér 1. \\ ${ }^{2}$ MTA-DE Biodiverzitás Kutatócsoport 4032 Debrecen, Egyetem tér 1. \\ ${ }^{3}$ MTA Ökológiai Kutatóközpont 2163 Vácrátót, Alkotmány út 2-4. \\ ${ }^{4}$ Kiskunsági Nemzeti Park Igazgatóság 6000 Kecskemét, Liszt Ferenc utca 19. \\ ${ }^{5}$ MTA-DE Lendület Funkcionális és Restaurációs Ökológiai Kutatócsoport \\ 4032 Debrecen, Egyetem tér 1. \\ ${ }^{6}$ Debreceni Egyetem, Agrár Kutatóintézetek és Tangazdaság (AKIT) Karcagi \\ Kutatóintézet 5300 Karcag, Kisújszállási út 166. \\ ${ }^{7}$ MTA Posztdoktori Kutatói Program, MTA TKI 1051 Budapest, Nádor utca 7. \\ e-mail*: kelemen.andras12@gmail.com
}

\begin{abstract}
Összefoglaló: A legelők megfelelő minőségének hosszútávú fenntartása szempontjából fontos ismernünk az elfogyasztott fitomassza mennyiségét és az állatok legeléspreferenciáját. Kutatásunkban turjánvidéki rétsztyeppeken vizsgáltuk a fitomassza frakciók fogyását és azt, hogy milyen tulajdonságokkal rendelkező növényeket kedvelnek a marhák. A vizsgált gyep két területre (legelési egységre) volt osztva, az egyik terület a vizsgálat évében a mintavétel időpontjáig (június közepe) még nem volt legeltetve (kontroll), a másikat a vizsgálatot megelőzően három hónapig legeltették. Mindkét területen $70 \mathrm{db}, 20 \times 20 \mathrm{~cm}$-es fitomassza mintát vettünk, melyeket fajonként szétválogattunk, különválogattuk az avart és a mohát is. A legeléspreferencia jelleg alapú elemzése során a 29 leggyakoribb fajt vizsgáltuk. A marhák a mohát és az avart csak kis mértékben fogyasztották, ezzel szemben az élö fitomassza 65\%-át elfogyasztották, a kétszikủeket és az egysziküeket hasonló arányban. Két levéltulajdonság mutatott szignifikáns összefüggést a legeléspreferenciával: a nagyobb fajlagos levélterületü és a magasabb nitrogéntartalmú fajokat kedvelték leginkább. Eredményeink alapján látható, hogy a legeltetéssel való területkezelés hosszú távú tervezését segíti a növényzet biomasszájának mérése, illetve a növények tápértékének becslése, amelynek jó indikátora néhány egyszerüen mérhető növényi tulajdonság, mint amilyen a fajlagos levélterület.
\end{abstract}

Kulcsszavak: avar, fitomassza, funkcionális jellegek, rétsztyepp, szelektív legelés, tápérték, területkezelés 


\section{Bevezetés}

A gyepi biodiverzitás fenntartása és a gyepek állapotának javítása érdekében elengedhetetlen olyan hasznosítást végezni rajtuk, amely létrejöttük és korábbi tipikus állapotuk kialakulásához hozzájárult, ez lehet legelés, kaszálás vagy akár égetés (Kelemen et al. 2014, Török et al. 2014, Valkó et al. 2016a, Valkó et al. 2017). A legelők megfelelő kezelésének fenntartása természetvédelmi és gazdasági szempontból is sokkal hatékonyabb, mint a leromlott területek rekonstrukciója (Török et al. 2012 a,b, Valkó et al. 2016b), emellett a legeltetés a helyreállított területeken is hasznos kezelés (Deák et al. 2015, Valkó et al. 2017). A legeltetés jelentős szerepet tölt be a fitomassza szezonális eltávolításában, az avar-felhalmozódás és a cserjésedés mérséklésében, megelőzésében (Deák et al. 2011, Házi et al. 2012). A legeltetés a zárt gyepekben időről időre megnyit olyan szabad foltokat, amelyekben új növényegyedek telepedhetnek meg, emellett a legelö állatok endo- és ektozoochoriával sok faj propagulumait szállíthatják a legelőkön (Kelemen et al. 2015, Mouissie et al. 2005). A legelők megfelelő minőségének hosszútávú fenntartása szempontjából fontos ismernünk az elfogyasztott fitomassza mennyiségét és az állatok legeléspreferenciáját, azaz azt, hogy mely fajokat részesítik előnyben. Az állatok szelektív legelése megváltoztathatja a gyepek fajösszetételét és a vegetáció jellegeloszlását, bizonyos tulajdonságokkal rendelkező fajok feldúsulhatnak a vegetációban, míg mások visszaszorulhatnak (Tóth et al. 2016, Török et al. 2016).

Kutatásunkban szarvasmarhával legeltetett, fajgazdag rétsztyeppeken vizsgáltuk az egyes fitomassza frakciók fogyását legelés hatására és az állatok legeléspreferenciáját. A következő fő kérdésekre kerestük a választ: (i) A fö fitomassza frakciók (moha, avar, kétszikü, egyszikü) mekkora részét legelik le a marhák? (ii) Milyen tulajdonságok különböztetik meg a preferált és a nem preferált edényes növényfajokat?

\section{Módszerek}

\section{Vizsgálati terület és mintavétel}

A vizsgálati terület a Kiskunsági Nemzeti Parkban található, Kunpeszér mel-

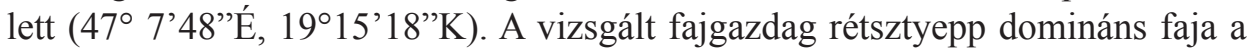
Molinia caerulea, több orchidea faj, illetve sok további védett faj élőhelye (Kelemen et al. 2017, Molnár et al. 2008, Vadász et al. 2016). A területet április és november között, közepes intenzitással (0,3-0,5 állategység/ha) legeltetik. A vizsgált gyep két, egymással szomszédos területre (legelési egységre) volt osztva. Az 
egyik (kontroll terület) a vizsgálat évében (2014), a mintavétel időpontjáig (június közepe) még nem volt legeltetve, míg a másikat az adott évben április óta legeltették (legelt terület). Mindkét területen (a kontroll és a legelt legelöegységben) $70 \mathrm{db}, 20 \times 20 \mathrm{~cm}$-es fitomassza mintát vettünk, amelyeket szárítás után fajonként szétválogattunk és különválogattuk az avart és a mohát is, a különválogatott egységek száraztömegét lemértük és megszámoltuk a fajok virágzó vagy termést érlelő hajtásainak számát.

\section{Adatelemzés}

A fö fitomassza frakciók és az egyes fajok fitomasszájának tömegeit $\left(\mathrm{g} / \mathrm{m}^{2}\right)$, illetve az egysziküek és a kétsziküek virágzó hajtás- és fajszámát a normalitás (ShapiroWilk próba) és varianciaegyezőség (F-teszt) függvényében t-teszt, Welch t-teszt, vagy Mann-Whitney U teszt segítségével vetettük össze a kontroll és a legelt terület között. A jelleg alapú elemzésbe azokat a fajokat vontuk be, amelyek a legelt és a nem legelt területen vett mintáinknak is minimum 10\%-ában jelen voltak. 29 ilyen faj volt, amelyek az összes élő biomasszának a 92,5\%-át alkották. A fajok preferáltságát három kategóriára osztottuk fogyásuk (a kontroll és a legelt területen detektált átlagos mennyiség közti különbség) alapján: 1. nem kedvelt - nincs szignifikáns különbség az adott faj kontroll és legelt területen detektált fitomasszája között; 2. közepesen kedvelt - fitomasszája szignifikánsan kisebb a legelt területen, de a fogyás nem nagyobb, mint az élő fitomassza átlagos fogyása; 3. nagyon kedvelt - fitomasszája szignifikánsan kisebb a legelt területen és a fogyás nagyobb, mint az élő fitomassza átlagos fogyása (1. táblázat). A fajok 3-3 egyedén mértük a következő tulajdonságokat: levél szárazanyag-tartalom (\%), levél száraz tömeg $(\mathrm{mg})$, levél terület $\left(\mathrm{mm}^{2}\right)$, fajlagos levélterület (SLA; $\left.\mathrm{mm}^{2} / \mathrm{mg}\right)$. Mértük továbbá a fajok hajtásainak nitrogén- és foszfortartalmát ( $\mathrm{m} / \mathrm{m} \%)$ (1. táblázat). Emellett meghatároztuk az adott faj hajtásainak szőrözöttségét és a fajok átlagos magasságát, Király (2009) alapján. Annak vizsgálatára, hogy a különböző preferáltság kategóriákba tartozó fajok eltérnek-e egymástól az adott jellegeik alapján ANOVA-t és Fisher LSD post-hoc tesztet használtunk.

\section{Eredmények}

A fö fitomassza frakciók közül az avar és a moha fogyása nem volt szignifikáns. Az edényes növények élö biomasszája szignifikánsan kevesebb volt a legelt területen a kontrollhoz viszonyítva, ez mind a kétsziküek, mind az egyszikűek esetében igaz volt (2. táblázat). A fajléptékü elemzésbe vont 29 faj biomasszájának fogyását az 1 . táblázatban adjuk meg. 
1. táblázat: A 29 leggyakoribb faj biomasszájának fogyása és funkcionális jellegeik. Magyarázat: M- Mann-Whitney-próba; W- Welch t-teszt; n.s - nem szignifikáns; * $-\mathrm{p}<0,05$; ** $-\mathrm{p}<0,01$; $* * *-p<0,001$; Pref. - preferáltsági kategória ( 1 - nem kedvelt; 2 - közepesen kedvelt; 3 - nagyon kedvelt); LDMC - levél szárazanyag-tartalom; LA - levélterület; SLA - fajlagos levélterület; N hajtás nitrogéntartalma.

\begin{tabular}{|c|c|c|c|c|c|c|c|}
\hline Faj & $\begin{array}{c}\text { Fogyás } \\
(\%)\end{array}$ & Teszt & Pref. & $\begin{array}{c}\text { LDMC } \\
(\%)\end{array}$ & $\begin{array}{c}\text { LA } \\
\left(\mathrm{mm}^{2}\right)\end{array}$ & $\begin{array}{c}\text { SLA } \\
\left(\mathrm{mm}^{2} / \mathrm{mg}\right)\end{array}$ & $\begin{array}{c}\mathrm{N} \\
(\mathrm{m} / \mathrm{m} \%)\end{array}$ \\
\hline Achillea asplenifolia & - & M; n.s. & 1 & 26,78 & 396,02 & 13,43 & 1,32 \\
\hline Agropyron repens & 76,98 & $\mathrm{~W} ; * *$ & 3 & 48,00 & 1226,59 & 13,57 & 1,36 \\
\hline Agrostis stolonifera & 34,23 & $\mathrm{M} ; *$ & 2 & 43,49 & 110,28 & 8,61 & 1,38 \\
\hline Carex flacca & 64,83 & $\mathrm{M} ; *$ & 2 & 41,81 & 1159,97 & 13,06 & 1,27 \\
\hline Carex panicea & 63,25 & $\mathrm{~W} ; * *$ & 2 & 41,34 & 869,22 & 13,47 & 1,34 \\
\hline Carex tomentosa & 64,14 & $\mathrm{~W} ; *$ & 2 & 62,70 & 168,30 & 15,82 & 1,32 \\
\hline Centaurea jacea & 79,47 & $\mathrm{M} ; * * *$ & 3 & 23,89 & 887,66 & 11,49 & 1,65 \\
\hline Chrysopogon gryllus & 9,79 & $\mathrm{M} ; *$ & 2 & 36,79 & 1809,36 & 12,24 & 1,47 \\
\hline Dactylis glomerata & 63,85 & $\mathrm{~W} ; * *$ & 2 & 38,04 & 2520,39 & 12,15 & 0,94 \\
\hline Daucus carota & 95,41 & $\mathrm{M} ; * * *$ & 3 & 30,30 & 3661,16 & 13,09 & N.A. \\
\hline Deschampsia caespitosa & - & M; n.s. & 1 & 36,71 & 2262,72 & 8,64 & 1,08 \\
\hline Festuca pratensis & 13,51 & $\mathrm{M} ; * *$ & 2 & 31,25 & 1177,04 & 15,76 & 1,42 \\
\hline Festuca pseudovina & - & M; n.s. & 1 & 40,94 & 41,23 & 15,96 & 1,08 \\
\hline Galium verum & 91,05 & $\mathrm{M} ; * * *$ & 3 & 75,28 & 16,86 & 4,95 & 1,70 \\
\hline Holoschoenus romanus & - & W; n.s. & 1 & 44,99 & 402,62 & 4,94 & 1,23 \\
\hline Inula bitannica & 10,29 & $\mathrm{M} ; * *$ & 2 & 23,35 & 581,45 & 17,01 & N.A. \\
\hline Juncus subnodulosus & - & M; n.s. & 1 & 30,10 & 150,15 & 6,30 & N.A. \\
\hline Koeleria cristata & - & M; n.s. & 1 & 46,45 & 236,35 & 5,17 & 1,50 \\
\hline Leontodon hispidus & 87,21 & $\mathrm{M} ; * *$ & 3 & 12,99 & 1611,75 & 18,27 & 1,91 \\
\hline Lotus corniculatus & 81,8 & $\mathrm{M} ; *$ & 3 & 21,81 & 120,98 & 20,50 & 2,07 \\
\hline Molinia caerulea & 92,57 & $\mathrm{M} ; * * *$ & 3 & 48,56 & 1110,73 & 9,72 & 1,57 \\
\hline Picris hieracioides & 77,41 & $\mathrm{~W} ; *$ & 3 & 24,20 & 1197,51 & 13,88 & N.A. \\
\hline Plantago lanceolata & - & M; n.s. & 1 & 27,96 & 1285,40 & 10,70 & 1,78 \\
\hline Plantago media & - & M; n.s. & 1 & 20,44 & 2577,03 & 10,10 & 1,38 \\
\hline Poa angustifolia & - & M; n.s. & 1 & 47,81 & 200,13 & 7,36 & 1,31 \\
\hline Potentilla recta & - & M; n.s. & 1 & 41,40 & 1660,92 & 10,61 & N.A. \\
\hline Schoenus nigricans & - & M; n.s. & 1 & 38,43 & 391,20 & 8,49 & N.A. \\
\hline Serratula tinctoria & 56,07 & $\mathrm{M} ; * * *$ & 2 & 27,60 & 4235,15 & 9,78 & 1,62 \\
\hline Tetragonolobus maritimus & 81,85 & $\mathrm{M} ; *$ & 3 & 22,87 & 1016,82 & 18,29 & 2,07 \\
\hline
\end{tabular}


2. táblázat: A fő fitomassza frakciók tömegei és fogyása. Magyarázat: $M$ - Mann-Whitney-próba; W - Welch t-teszt; n.s - nem szignifikáns; $* * *-p<0,001$.

\begin{tabular}{lcccc}
\hline & Kontroll & Legelt & Fogyás & Teszt \\
\hline \multicolumn{1}{c}{ Fitomassza $\left(\mathrm{g} / \mathrm{m}^{2}\right)$} & & & & \\
Avar & 174,8 & 147,4 & - & $\mathrm{M} ; \mathrm{n} . \mathrm{s}$ \\
Moha & 2,55 & 2,54 & - & $\mathrm{M} ; \mathrm{n} . \mathrm{s}$ \\
Élő edényes növény & 272,7 & 94,9 & $65,20 \%$ & $\mathrm{M} ; * * *$ \\
Kétszikủ & 58,8 & 21,1 & $64,20 \%$ & $\mathrm{M} ; * * *$ \\
Egyszikü & 213,8 & 73,8 & $65,50 \%$ & $\mathrm{~W} ; * * *$ \\
Virágzó hajtásszám $\left(\mathrm{db} / \mathrm{m}^{2}\right)$ & & & \\
Összes & 235,7 & 34,3 & $85,50 \%$ & $\mathrm{M} ; * * *$ \\
Kétszikü & 30,4 & 4,6 & $84,70 \%$ & $\mathrm{M} ; * * *$ \\
Egyszikű & 205,4 & 29,6 & $85,60 \%$ & $\mathrm{M} ; * * *$ \\
Virágzó fajszám $\left(\mathrm{faj} / 0,04 \mathrm{~m}^{2}\right)$ & & & - \\
Összes & 2,9 & 0,9 & - & $\mathrm{M} ; * * *$ \\
Kétszikủ & 0,5 & 0,2 & - & $\mathrm{M} ; * * *$ \\
Egyszikü & 2,4 & 0,7 & $\mathrm{M} ; * *$ \\
\hline
\end{tabular}

A virágzó hajtásszám szignifikánsan alacsonyabb volt a legelt területen a kontrollhoz viszonyítva, ez igaz volt mind a kétszikủek, mind az egyszikủek esetében (2. táblázat). A virágzó fajszám is szignifikánsan alacsonyabb volt a legelt területen a kontrollhoz viszonyítva, szintén mind a kétsziküek, mind az egysziküek esetében (2. táblázat). 9 egyszikủ és 11 kétszikü faj volt, amely csak a legelt területen virágzott.

A különböző preferáltság kategóriákba tartozó fajok csupán két jellegük alapján tértek el szignifikánsan, a fajlagos levélterület (SLA) és a nitrogéntartalom alapján (SLA: ANOVA; $\mathrm{F}=7,47 ; \mathrm{p}<0,05$; nitrogéntartalom: ANOVA; $\mathrm{F}=10,67$; $\mathrm{p}<0,001)$. A preferált fajok csoportjaiban mindkét tulajdonság értékei magasabbak voltak (1. ábra).

\section{Értékelés}

A legtöbb vizsgálat a miénktöl eltérően nem a legelés hatására bekövetkezö közvetlen fitomassza változásokat vizsgálta, hanem a legelés hosszú távú hatását a biomasszára (Altesor et al. 2005, Bork et al. 2012). Az avar esetében hozzánk hasonlóan kimutatták, hogy közvetlenül csak kevéssé fogyasztják a marhák (Carilla et al. 2011), a legelőkön detektált alacsonyabb avarmennyiség leginkább az élő 

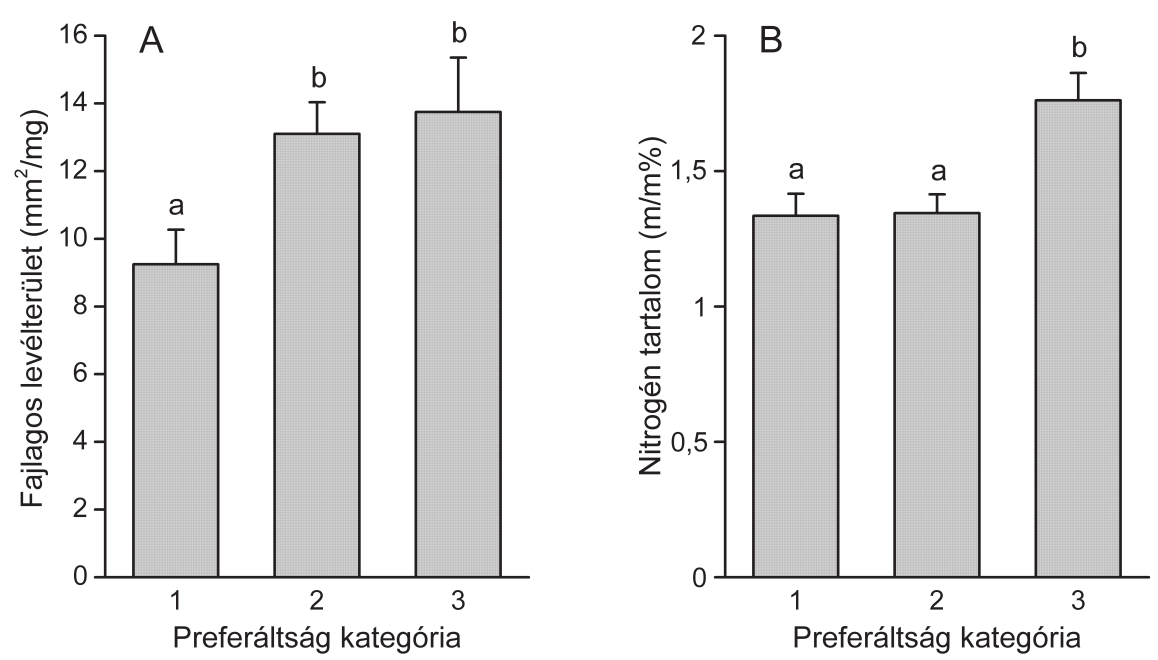

1. ábra: Fajlagos levélterület - A és hajtás nitrogéntartalom - B (átlag+standard hiba) a különböző preferáltsági kategóriába tartozó fajcsoportoknál. Az oszlopok fölötti különböző betűk a kategóriák közötti szignifikáns eltéréseket jelölik (Fisher LSD teszt; $p<0,05$ ). Magyarázat: 1 - nem kedvelt fajok; 2 - közepesen kedvelt fajok; 3 - nagyon kedvelt fajok.

fitomassza elfogyasztásának későbbi hatásából adódik (Kelemen et al. 2013). A marhalegelés mohákra gyakorolt hatását főleg mohák által dominált magashegységi vegetációban vizsgálták, ahol kimutatták, hogy a tavaszi legeltetés 50\%-kal csökkenti a mohapárnák borítását (Memmot et al. 1998). Vizsgálatunk alapján látható, hogy ott, ahol a mohákon kívül edényes vegetáció is bőségesen rendelkezésére áll a szarvasmarháknak, amely takarja is a mohákat, ott a mohák fogyasztása elenyészö. A legelés általában megnöveli a vegetáció primer produkcióját, Altesor et al. (2005) tanulmánya szerint ez a növekedés több, mint $50 \%$ is lehet. Ennek ellenére, mivel a primer produktum egy része elfogyasztásra kerül, a legeltetés felhagyása után a vegetáció biomasszája általában növekszik (Hill et al. 1992). Az edényes növények élő biomasszájának legelés hatására történő közvetlen fogyásával kapcsolatban egyes cikkek a miénkhez hasonló eredményre jutottak (Kauffman et al. (2004) - 63,1\%-os csökkenés; Amiaud et al. (2008) - 67,9\%os csökkenés; Hofstede et al. (1995) - 63\%-os csökkenés). A szakirodalomban találunk példát az általunk detektálttól eltérö fitomassza fogyasztásra is, Carilla et al. (2011) tanulmányában a jelen vizsgálatéhoz hasonló legelési intenzitás mellett 4-10\%-os élő fitomassza fogyasztásról számol be, míg Isbell \& Wilsey (2011) magas legelési nyomásnál $80 \%$-os élő fitomassza fogyást detektált. 
A legelés közvetlen hatása természetesen negatív a virágzó hajtás- és fajszámra is , de itt is különbséget kell tenni a rövid távú és a hosszú távú hatás között. Anderson \& Frank (2003) arról számolt be, hogy rendszeresen legelt területeken, amelyeket az adott évben még nem legeltettek, kétszer akkora a virágzó hajtásszám, mint a felhagyott területeken. A fentiek alapján hangsúlyozzuk, hogy ahhoz, hogy a legtöbb faj reproduktív szaporodása hosszú távon megvalósuljon, kedvezőtlen az, ha egy területet minden évben ugyan abban a periódusban legeltetnek, ehelyett javasolható a térben és időben mozaikos legeltetés (Vadász et al. 2016).

Eredményeink korábbi publikációkkal összhangban azt mutatják, hogy a szarvasmarhák leginkább a magas tápértékkel rendelkező növényeket részesítik előnyben (Coppock et al. 1986, Diaz et al. 2001, Illius et al. 1992). Minél nagyobb egy faj nitrogéntartalma, annál magasabb a tápértéke (Mattson 1980). A nagy fajlagos levélterülettel (SLA) rendelkező fajok leveleiben általában magas a táplálékkészítő alapszövet aránya, ezért pozitív összefüggés van az SLA és a nitrogéntartalom között (Westoby 1998).

Eredményeink alapján látható, hogy egy terület legelő állat eltartó képességét és hosszú távú kezelését jól lehet tervezni a növényzet biomasszájának mérésével, illetve növények tápértékének becslésével, amelynek jó indikátora néhány egyszerüen mérhető növényi tulajdonság, mint amilyen a fajlagos levélterület. A legelők hosszú távú fenntartása érdekében természetvédelmi szempontból a közepes legelési intenzitással történő, térben és időben mozaikos legelés javasolható, és az sem feltétlenül baj, ha maradnak kisebb kevésbé legeltetett vagy éppen túllegeltetett foltok.

Köszönetnyilvánítás - A tanulmány felelős szerzőjét az MTA Posztdoktori Kutatói Program Prémium Posztdoktori (PPD-003/2016) támogatása támogatja. Köszönjük továbbá a következő támogatásokat: MTA OTKA PD 111807 (VO), NKFI FK 124404 (VO), NKFI KH 126476 (VO), OTKA K 116239 (TB), NKFI KH 12647 (TB), NKFIH K 119225 (TP), NKFI PD 124548 (MT), OTKA PD 115627 (DB), Bolyai János Ösztöndíj (DB, VO), ÚNKP-17-4-III-DE-151 and ÚNKP-17-4-III-DE-160 OV (DB, VO).

\section{Irodalomjegyzék}

Altesor, A., Oesterheld, M., Leoni, E., Lazama, F. \& Rodríguez, C. (2005): Effect of grazing on community structure and productivity of a Uruguayan grassland. - Plant Ecol. 179: 83-9. doi: https://doi.org/10.1007/s11258-004-5800-5

Amiaud, B., Touzard, B., Bonis, A. \& Bouzillé, J.-B. (2008): After grazing exclusion, is there any modification of strategy for two guerrilla species: Elymus repens (L.) Gould and Agrostis stolonifera (L.)? - Plant Ecol. 197: 107-117. doi: https://doi.org/10.1007/s11258-007-9364-Z

Anderson, M. T. \& Frank, D. A. (2003): Defoliation effects on reproductive biomass: importance of scale and timing. - J. Range Manage. 56: 501-516. doi: https://doi.org/10.2307/4003843 
Bork, E., Willms, W., Tannas, S. \& Alexander, M. (2012): Seasonal patterns of forage availability in the Fescue grasslands under contrasting grazing histories. - Rangeland Ecol. Manag. 65: 47-55. https://doi.org/10.2111/REM-D-11-00087.1

Carilla, J., Aragón, R. \& Gurvich, D. E. (2011): Fire and grazing differentially affect aerial biomass and species composition in Andean grasslands. - Acta Oecol. 37: 337-345. doi: https://doi. org/10.1016/j.actao.2011.03.006

Coppock, D. L., Swift, D. M. \& Ellis, J. E. (1986): Seasonal nutritional characteristics of livestock diets in a nomadic pastoral ecosystem. - J. Appl. Ecol. 23: 585-595. doi: https://doi. org $/ 10.2307 / 2404038$

Deák, B., Valkó, O., Kelemen, A., Török, P. Miglécz, T., Ölvedi, T., Lengyel, Sz. \& Tóthmérész, B. (2011): Litter and graminoid biomass accumulation suppresses weedy forbs in grassland restoration. - Plant Biosyst. 145: 730-737. doi: https://doi.org/10.1080/11263504.2011.601336

Deák, B., Valkó, O., Török, P., Kelemen, A., Miglécz, T., Szabó, Sz., Szabó, G. \& Tóthmérész, B. (2015): Micro-topographic heterogeneity increases plant diversity in old stages of restored grasslands. - Basic. Appl. Ecol. 16: 291-299. doi: https://doi.org/10.1016/j.baae.2015.02.008

Díaz, S., Noy-Meir, I. \& Cabido, M. (2001): Can grazing response of herbaceous plants be predicted from simple vegetative traits? - J. Appl. Ecol. 38: 497-508. doi: https://doi.org/10.1046/j.13652664.2001.00635.x

Házi, J., Penksza, K., Bartha, S., Hufnagel, L., Tóth, A., Gyuricza, Cs. \& Szentes, Sz. (2012): Cut mowing and grazing effects with grey cattle on plant species composition in case of Pannon wet grasslands. - Appl. Ecol. Env. Res. 10: 223-231. doi: https://doi.org/10.15666/aeer/1003 223231

Hill, M. O., Evans, D. F. \& Bell, S. A. (1992): Long-term effects of excluding sheep from hill pastures in North Wales. - J. Ecol. 80: 1-13. doi: https://doi.org/10.2307/2261058

Hofstede, R. G. M., Castillo, M.,X. M. \& Osorio, C. M. R. (1995): Biomass of grazed, burned, and undisturbed paramo grasslands, Colombia. I. Aboveground Vegetation. - Arct. Antarct. Alp. Res. 27: 1-12. doi: https://doi.org/10.2307/1552062

Illius, A. W., Clark, D. A. \& Hodgson, J. (1992): Discrimination and patch choice by sheep grazing grass-clover swards. - J. Anim. Ecol. 61: 183-194. doi: https://doi.org/10.2307/5521

Kauffman, J. B., Thorpe, A. S. \& Brookshire, J. E. N. (2004): Livestock exclusion and belowground ecosystem responses in riparian meadows of eastern oregon. - Ecol. Appl. 14: 1671-1679. doi: https://doi.org/10.1890/03-5083

Kelemen, A., Lazzaro, L., Besnyői, V., Albert, Á.-J., Konečná, M., Dobay, G., Memelink, I., Adamec, V., Götzenberger, L., de Bello, F., Le Bagousse-Pinguet, Y. \& Lepš J. (2015): Net outcome of competition and facilitation in a wet meadow changes with plant's life stage and community productivity. - Preslia 87 : 347-361.

Kelemen, A., Tölgyesi, C., Kun, R., Molnár, Z., Vadász, C. \& Tóth, K. (2017): Positive small-scale effects of shrubs on diversity and flowering in pastures. - Tuexenia 37: 399-413. doi: https://doi. org/10.14471/2017.37.009

Kelemen, A., Török, P., Valkó, O., Deák, B., Miglécz, T., Tóth, K., Ölvedi, T. \& Tóthmérész, B. (2014): Sustaining recovered grasslands is not likely without proper management: vegetation changes after cessation of mowing. - Biodivers. Conserv. 23: 741-751. doi: https://doi. org/10.1007/s10531-014-0631-8

Kelemen, A., Török, P., Valkó, O., Miglécz, T. \& Tóthmérész, B. (2013): Mechanisms shaping plant biomass and species richness: plant strategies and litter effect in alkali and loess grasslands. $-J$. Veg. Sci. 24: 1195-1203. doi: https://doi.org/10.1111/jvs.12027

Király, G. (szerk.) (2009): Új magyar füvészkönyv. Magyarország hajtásos növényei. Határozókulcsok. - Aggteleki Nemzeti Park Igazgatóság, Jósvafö, 616 p. 
Mattson, W. J. Jr. (1980): Herbivory in relation to plant nitrogen content. - Ann. Rev. Ecol. Syst. 11: 119-161. doi: https://doi.org/10.1146/annurev.es.11.110180.001003

Memmott, K. L., Anderson, V. J. \& Monsen, S. B. (1998): Seasonal grazing impact on cryptogamic crusts in a Cold desert Ecosystem. - J. Range. Manage. 51: 547-550. doi: https://doi. org $/ 10.2307 / 4003374$

Molnár, Z., Bíró, M., Bölöni, J. \& Horváth, F. (2008): Distribution of the (semi-)natural habitats in Hungary I. Marshes and grasslands. - Acta Bot. Hung. 50: 59-105. doi: https://doi.org/10.1556/ ABot.50.2008.Suppl.6

Mouissie, A. M., Vos, P., Verhagen, H. M. C. \& Bakker, J. P. (2005). Endozoochory by free-ranging, large herbivores: ecological correlates and perspectives for restoration. Basic. Appl. Ecol. 6: 547-558. doi: https://doi.org/10.1016/j.baae.2005.03.004

Tóth, E., Deák, B., Valkó, O., Kelemen, A., Miglécz, T., Tóthmérész, B. \& Török, P. (2018): Livestock type is more crucial than grazing intensity: Traditional cattle and sheep grazing in shortgrass steppes. - Land Degrad. Dev. 29: 231-239. doi: https://doi.org/10.1002/ldr.2514

Török, P., Miglécz, T., Valkó, O., Kelemen, A., Deák, B., Lengyel, Sz. \& Tóthmérész, B. (2012a): Recovery of native grass biodiversity by sowing on former croplands: Is weed suppression a feasible goal for grassland restoration? - J. Nat. Conserv. 20: 41-48. doi: https://doi.org/10.1016/j. jnc.2011.07.006

Török, P., Miglécz, T., Valkó, O., Kelemen, A., Tóth, K., Lengyel, Sz. \& Tóthmérész, B. (2012b): Fast recovery of grassland vegetation by a combination of seed mixture sowing and low-diversity hay transfer. - Ecol. Eng. 44: 133-138. doi: http://doi.org/10.1016/j.ecoleng.2012.03.010

Török, P., Valkó, O., Deák, B., Kelemen, A., Tóth, E. \& Tóthmérész, B. (2016): Managing for species composition or diversity? Pastoral and free grazing systems of alkali grasslands. - Agric. Ecosyst. Environ. 234: 23-30. doi: https://doi.org/10.1016/j.agee.2016.01.010

Török, P., Valkó, O., Deák, B., Kelemen, A. \& Tóthmérész, B. (2014): Traditional cattle grazing in a mosaic alkali landscape: Effects on grassland biodiversity along a moisture gradient. PLoS ONE 9: e97095. doi: https://doi.org/10.1371/journal.pone.0097095

Vadász, C., Máté, A., Kun, R. \& Vadász-Besnyői, V. (2016): Quantifying the diversifying potential of conservation management systems: An evidence-based conceptual model for managing speciesrich grasslands. - Agric. Ecosys. Environ. 234: 134-141. doi: https://doi.org/10.1016/j. agee.2016.03.044

Valkó, O., Deák, B., Magura, T., Török, P., Kelemen, A., Tóth, K., Horváth, R., Nagy, D. D., Debnár, Zs., Zsigray, Gy., Kapocsi, I. \& Tóthmérész, B. (2016a): Supporting biodiversity by prescribed burning in grasslands - a multi-taxa approach. - Sci. Total Environ. 572: 1377-1384. doi: https:// doi.org/10.1016/j.scitotenv.2016.01.184

Valkó, O., Deák, B., Török, P., Kirmer, A., Tischew, S., Kelemen, A., Tóth, K., Miglécz, T., Radócz, Sz., Sonkoly, J., Tóth, E., Kiss, R., Kapocsi, I. \& Tóthmérész, B. (2016b): High-diversity sowing in establishment gaps: a promising new tool for enhancing grassland biodiversity. - Tuexenia 36: 359-378. doi: https://doi.org/10.14471/2016.36.020

Valkó, O., Deák, B., Török, P., Kelemen, A., Miglécz, T. \& Tóthmérész, B. (2017): Filling up the gaps - Passive restoration does work on linear landscape scars. - Ecol. Eng. 102: 501-508. doi: https://doi.org/10.1016/j.ecoleng.2017.02.024

Westoby, M. (1998): A leaf-height-seed (LHS) plant ecology strategy scheme. - Plant Soil. 199: 213-227. doi: https://doi.org/10.1023/A:1004327224729 


\title{
Consumption rate and dietary choice of cattle on meadow steppe vegetation
}

\author{
Nóra Balogh ${ }^{1}$, Béla Tóthmérész ${ }^{1}$, Orsolya Valkó1, Balázs Deák², \\ Tamás Miglécz ${ }^{1}$, Katalin Tóth ${ }^{2}$, Zsolt Molnár ${ }^{3}$, Csaba Vadász ${ }^{4}$, \\ Edina Tóth ${ }^{5}$, Réka Kiss ${ }^{1}$, Judit Sonkoly ${ }^{5}$, Péter Török ${ }^{5}$, \\ Károly Antal $^{6}$, Júlia Tüdősné Budai ${ }^{6}$ and András Kelemen ${ }^{1,7^{*}}$ \\ ${ }^{1}$ University of Debrecen, Department of Ecology, \\ H-4032 Debrecen, Egyetem tér 1, Hungary \\ ${ }^{2}$ MTA-DE Biodiversity and Ecosystem Services Research Group \\ H-4032 Debrecen, Egyetem tér 1, Hungary \\ ${ }^{3}$ MTA Centre for Ecological Research, Institute of Ecology and Botany \\ H-2163 Vácrátót, Alkotmány út 2-4, Hungary \\ ${ }^{4}$ Kiskunság National Park Directorate \\ H-6000 Kecskemét, Liszt Ferenc utca 19, Hungary \\ ${ }^{5}$ MTA-DE Lendület Functional and Restoration Ecology Research Group \\ H-4032 Debrecen, Egyetem tér 1, Hungary \\ ${ }^{6}$ Karcag Research Institute, RIEF, University of Debrecen \\ H-5300 Karcag, Kisújszállási út 166, Hungary \\ ${ }^{7}$ MTA TKI, ${ }^{7}$ MTA's Post Doctoral Research Program, \\ H-1051 Budapest, Nádor utca 7, Hungary \\ e-mail*: kelemen.andras12@gmail.com
}

\begin{abstract}
Grasslands have been exposed to detrimental land-use changes worldwide in the recent past, including agricultural intensification and the cessation of management. The maintenance of traditional management and understanding its effects on vegetation is essential for effective biodiversity conservation. Therefore we studied the direct effects of grazing on species-rich meadow steppes and the underlying mechanisms of dietary choice of cattle using trait-based approaches. Our study site was divided into two adjacent grazing units, managed differently in the study year. The control unit was ungrazed in the year of sampling while the other one was grazed for three months before the sampling with $0.3-0.5$ animal unit/ha. We collected 70 randomly selected above-ground biomass samples $(20 \mathrm{~cm} \times 20 \mathrm{~cm})$ in both units in the middle of June 2014. Samples were sorted to litter, moss biomass and green biomass of each vascular plant species separately, and then dry weights were measured. The consumption of the litter and moss biomass was negligible, while cattle ingested $65 \%$ of green biomass of vascular plants. Cattle showed significant preference to species characterized by high specific leaf area and high nitrogen content. Our study underline that it is important to consider the productivity and plant traits (i.e. SLA) during the planning of a sustainable grazing regime.
\end{abstract}

Keywords: biomass, grassland, grazing, leaf traits, litter, nitrogen content, palatability, SLA 